\title{
Happamat sulfaattimaat -potentiaalinen kasvihuonekaasujen lähde?
}

\author{
Seija Virtanen ${ }^{1)}$, Miloslav Šimek ${ }^{2,3)}$ Asko Simojoki ${ }^{1)}$, Václav Krištůfek ${ }^{3)}$ ja Markku Yli-Halla ${ }^{1)}$ \\ ${ }^{1)}$ Elintarvike- ja ympäristötieteden laitos, PL 27, 00014 Helsingin yliopisto, \\ seija.virtanen@helsinki.fi, asko.simojoki@helsinki.fi, markku.yli-halla@helsinki.fi \\ 2) Biology Centre AS CR, Institute of Soil Biology, Na Sádkách 7, 37005 České Budějovice, \\ Tsekin tasavalta \\ 3) University of South Bohemia, Faculty of Science, Branišovská 31, 37005 České Budějovice, \\ Tsekin tasavalta
}

\section{Tiivistelmä}

Euroopan suurimmat happamien sulfaattimaiden esiintymät sijaitsevat Suomessa. Pääsääntöisesti entisen Litorina-meren rantaviivan alapuolella olevien sulfaattimaiden alasta on arviolta 67 000-130 000 ha maatalouskäytössä; eniten niitä on Pohjanlahden rannikkoseuduilla. Maan kohoamisen ja viljelyn vaatiman tehokkaan kuivatuksen vuoksi niiltä purkautuvat valumavedet ovat happamia ja metallipitoisia, mikä heikentää vastaanottavien vesistöjen ekologista tilaa. Samalla, kun veden kyllästämät hapettomat maakerrokset muuttuvat maan kuivuessa hapellisiksi, myös mikrobien kasvuolosuhteet muuttuvat. Ilmaston lämpeneminen voi tehostaa mikrobitoimintaa, minkä vuoksi happamilla sulfaattimailla orgaanisen hiilen ja ravinnevarojen mobilisoitumisen tehostuessa maan kasvihuonekaasupäästöt voivat kasvaa..

Tämän pilottitutkimuksen tavoitteena oli vertailla happaman sulfaattimaan (Sulfic Cryaquept) ja ei-happaman vertailumaan (Aquic Haplocryoll) mikrobiaktiivisuutta sekä maakerrosten hiili- ja typpivarantoja. Maan eri horisonteista otettiin näytteitä $180 \mathrm{~cm}: n$ syvyyteen asti, ja niiden orgaaninen hiili ja kokonaistyppi määritettiin kuivapoltolla ja mineraalityppi uutettiin $2 \mathrm{M} \mathrm{KCl-liuoksella.}$ Maakerrosten hiili- ja typpivarannot laskettiin kertomalla mitatut ainepitoisuudet $\left(\mathrm{g} \mathrm{kg}^{-1}\right)$ kerrosten irtotiheyksillä $\left(\mathrm{kg} \mathrm{dm}^{-3}\right)$. Samoista maakerroksista määritettiin maahengitys (BR), substraattilisäyksellä indusoitu maahengitys (SIR) ja dehydrogenaasientsyymin aktiivisuus (DHA).

Tulokset osoittivat, että happaman sulfaattimaan pohjamaassa (C-horisontti, syvyys 128 -180 $\mathrm{cm})$ on hehtaaria kohti lasketut orgaanisen hiilen $\left(\mathrm{C}_{\text {org }}\right)$, kokonaistypen $\left(\mathrm{N}_{\text {tot }}\right)$ ja mineraalitypen $\left(\mathrm{N}_{\min }\right)$ varannot (110 $\mathrm{Mg} \mathrm{C}_{\text {org }}, 15 \mathrm{Mg} \mathrm{N}_{\text {tot }}$ ja $\mathrm{N}_{\min } 330 \mathrm{~kg}$ ) ovat huomattavasti suuremmat kuin tavanomaisen peltomaan pohjakerroksessa (30 Mg $\mathrm{C}_{\text {org }}, 5 \mathrm{Mg} \mathrm{N}_{\text {tot }}$ ja $\mathrm{N}_{\text {min }} 110 \mathrm{~kg}$ ). Tutkitut maaprofiilit erosivat toisistaan myös mikrobiaktiivisuuden osalta. Happamassa sulfaattimaassa mikrobiaktiivisuus väheni pinnasta alaspäin vaihtumiskerrokseen asti (BC-horisontti), josta alaspäin $\mathrm{CO}_{2}-\mathrm{C}$ tuottona laskettu aktiivisuus kasvoi voimakkaasti (BR 2,1 $\mu \mathrm{g} \mathrm{g}^{-1} \mathrm{~h}^{-1}$, SIR $33 \mu \mathrm{g} \mathrm{g}^{-1} \mathrm{~h}^{-1}$ ja DHA $5.7 \mu \mathrm{g}$ TPF g ${ }^{-1} \mathrm{~h}^{-1} \mathrm{C}$ horisontissa). Tavanomaisen maan C-horisontissa mikrobiaktiivisuus oli huomattavasti pienempi (BR $0,5 \mu \mathrm{g} \mathrm{g}^{-1} \mathrm{~h}^{-1}$, SIR 7,5 $\mu \mathrm{g} \mathrm{g}^{-1} \mathrm{~h}^{-1}$ ja DHA $1,8 \mu \mathrm{g}$ TPF $\mathrm{g}^{-1} \mathrm{~h}^{-1}$ C-horisontissa). Jos maan olosuhteet muuttuvat mikrobeille suotuisiksi, runsaat ravinnevarannot ja vilkastunut mikrobitoiminta voivat johtaa maan hiili- ja typpivarantojen mobilisoitumiseen ja kasvihuonekaasupäästöjen lisääntymiseen. Kasvihuonekaasujen tuottoa viljellyissä happamissa sulfaattimaissa on tutkittu vasta vähän. Alustavat tulokset osoittavat, että lisätutkimuksille on tarvetta.

Asiasanat: Happamat sulfaattimaat, hiili, typpi, mikrobiaktiivisuus, kasvihuonekaasuemissiot 


\section{Johdanto}

Euroopan suurimmat happamien sulfaattimaiden esiintymät sijaitsevat Suomessa. Syntyhistoriansa takia ne esiintyvät pääsääntöisesti entisen Litorina-meren rantaviivan alapuolella; eniten Pohjanlahden rannikkoseuduilla. Maanviljelyssä sulfaattimaita on arviolta 67 000-130 000 ha (Yli-Halla ym., 1999). Happamat sulfaattimaat ovat ympäristön kannalta ongelmallisia, koska niiden happamat ja metallipitoiset valumavedet heikentävät purkuvesistöjen ekologista tilaa (Fältmarsch ym., 2008). Maan kohoaminen ja viljelyn vaatima tehokas kuivatus edistävät hapen diffuusiota maakerroksiin ja sulfidien hapettumista niissä, mikä johtaa sekä maan että valumavesien happamoitumiseen. Samalla kun veden kyllästämät hapettomat maakerrokset muuttuvat maan kuivuessa hapellisiksi, myös mikrobien kasvuolosuhteet muuttuvat. Koska happamien sulfaattimaiden pohjakerrosten on todettu sisältävän tavanomaista maata enemmän orgaanista hiiltä (Joukainen \& Yli-Halla, 2003) ja typpeä (Paasonen-Kivekäs \& Yli-Halla, 2005), näiden ravinnevarojen mobilisoituminen vilkastuneen mikrobitoiminnan seurauksena voi lisätä maan kasvihuonekaasupäästöjä. Ilmaston lämpeneminen voi vielä tehostaa tätä ilmiötä.

Tutkimuksemme tavoitteena oli selvittää happaman sulfaattimaan ja ei-happaman vertailumaan hiili- ja typpivarantoja sekä mikrobien aktiivisuutta eri maakerroksissa. Hypoteesimme oli, että happamassa sulfaattimaassa on tavanomaista maata suuremmat orgaanisen hiilen ja typen varannot. Mikrobien aktiivisuutta happaman sulfaattimaan eri kerroksissa ei ole aiemmin tutkittu, joten tältä osin tutkimuksemme tulokset antavat aivan uutta tietoa.

\section{Aineisto ja menetelmät}

Tutkimukseen valittiin kaksi Helsingin yliopiston Viikin koetilan savipeltoa, joista toinen on hapanta sulfaattimaata (Sulfic Cryaquaept) ja toinen tavanomaista savimaata (Aquic Haplocryoll) (Mokma ym. 2000, Yli-Halla ym., 2000). Hapan sulfaattimaapelto (Patoniitty: $60^{\circ} 13^{\prime} \mathrm{N}, 2^{\circ} 0^{\prime} \mathrm{E}$ ) on meren pinnan tasolla, ja se on pengerryskuivattu viljelyä varten 1950-luvulla. Koska pellolla pohjavesi nousee luontaisesti maanpinnan tasoon, lasketaan se kasvukauden aikana pumppaamalla noin metrin syvyyteen. Pellolla on viljelty eri viljakasveja. Tavanomaista maata edustava pelto (Alaniitty: $60^{\circ} 13^{\prime}$ $\mathrm{N}, 25^{\circ} 1^{\prime}$ E) on noin metrin merenpinnan yläpuolella, ja se on salaojitettu1950-luvulla. Alaniitty on laidunmaata. Taulukoon 1 on koottu maiden kemiallisia ja fysikaalisia ominaisuuksia maakerroksittain aiemmin maannosten nimeämisen yhteydessä tehdyistä tutkimuksista.

Maanäytteet otettiin 23.9.2009 suurista koekuopista, jotka kaivettiin kaivinkoneella pohjamaahan asti, Patoniityllä $180 \mathrm{~cm}$ ja Alaniityllä $165 \mathrm{~cm}$ syvyyteen. Näytteenoton aikana kuoppiin suotautuva vesi pumpattiin pois. Näytteet kemiallisiin ja mikrobiologisiin määrityksiin otettiin eri maakerroksista kokoomanäytteinä, ja irtotiheyden määrittämistä varten kolmena rinnakkaisena. Mineraalitypen määritystä varten näytteet pakastettiin välittömästi.

Kokonaishiili ja -typpi määritettiin kuivapoltolla $\left(+900{ }^{\circ} \mathrm{C}\right.$, vario Max $\left.\mathrm{CN}\right)$. Kaikki niissä oleva hiili oletettiin orgaaniseksi, koska suomalaisissa maissa epäorgaanisen hiilen osuus on yleensä hyvin pieni. Mineraalitypen pitoisuudet määritettiin sulatetuista maanäytteistä uuttamalla ne uuttosuhteella 1:2,5 $2 \mathrm{M} \mathrm{KCl}$-liuokseen (Esala, 1995). Ammonium- $\left(\mathrm{NH}_{4}{ }^{+}-\mathrm{N}\right)$, nitriitti- $\left(\mathrm{NO}_{2}{ }^{-} \mathrm{N}\right)$ ja nitraattityppi $\left(\mathrm{NO}_{3}{ }^{-} \mathrm{N}\right)$, määritettiin kolorimetrisesti autoanalysaattorilla (LaChat Instruments, QuikChem 8000). Määrityksen laatu varmistettiin 20 näytteen välein tunnetuilla näytteillä. Maan typpipitoisuudet $\mathrm{mg} \mathrm{kg}^{-1}$ muutettiin kilogrammoiksi hehtaarille maakerrosten irtotiheyksien (Brasher ym., 1966) avulla.

Maahengitys (BR) määritettiin tuoreesta maasta inkubaatiokokeella, jossa mitattiin hiilidioksidin tuotto 2 ja 24 h kuluttua kokeen aloituksesta $\left(+25^{\circ} \mathrm{C}, 24 \mathrm{~h}\right)$. Substraattilisäyksellä indusoitu hengitys (SIR) määritettiin lisäämällä tuoreeseen maahan glukoosia $\left(2 \mathrm{mg} \mathrm{g}^{-1}\right.$ kuivaa maata, $\left.+25{ }^{\circ} \mathrm{C}, \quad 0-3 \mathrm{~h}\right)$ ja mittaamalla $\mathrm{CO}_{2}$-tuotto aikayksikköä kohti. Molemmissa mittauksissa hiilidioksidipitoisuudet määritettiin kaasukromatografilla (Agilent Technologies 6850 GC). Dehydrogenaasientsyymin aktiivisuus (DHA) määritettiin kenttäkosteista maanäytteistä inkubaatiokokeella $\left(+37{ }^{\circ} \mathrm{C}, 24 \mathrm{~h}\right)$ mittaamalla trifenyyliformatsaanin määrä kokeen jälkeen spektrofotometrisesti aallonpituudella 485 nm (Casida ym., 1964, Dick ym., 1996). - Keskiarvojen erojen merkitsevyys testattiin Studentin t-testillä. 
Taulukko 1. Happaman sulfaattimaan ja tavanomaisen savimaan fysikaalisia ja kemiallisia ominaisuuksia kerroksittain (Mokma ym. 2000, Yli-Halla ym., 2000).

\begin{tabular}{|c|c|c|c|c|c|c|c|c|c|}
\hline \multirow[t]{3}{*}{ Kerros } & \multirow[t]{2}{*}{ Syvyys } & \multicolumn{3}{|c|}{ Raekokojakauma (mm) } & \multicolumn{2}{|c|}{$\mathrm{pH}^{\mathrm{a}}$} & \multirow[t]{2}{*}{$\mathrm{KVK}^{\mathrm{b}}$} & \multirow[t]{2}{*}{$\mathrm{BS}^{\mathrm{c}}$} & \multirow{3}{*}{$\begin{array}{c}\text { Kokonais } \\
\mathrm{S} \\
\mathrm{g} \mathrm{kg}^{-1}\end{array}$} \\
\hline & & $>0,05$ & $0,002-0,05$ & $<0,002$ & Tuore & Inkuboitu & & & \\
\hline & $\mathrm{cm}$ & $\%$ & $\%$ & $\%$ & & & $\mathrm{cmol} \mathrm{kg}^{-1}$ & $\%$ & \\
\hline \multicolumn{10}{|c|}{ Hapan sulfaattimaa } \\
\hline Ap & $0-28$ & 4 & 63 & 33 & 6,4 & 5,8 & 21,1 & 73 & 0,9 \\
\hline Bg1 & $28-36$ & 2 & 66 & 32 & 5,0 & 4,8 & 16,6 & 37 & 0,9 \\
\hline $\mathrm{Bg} 2$ & $36-72$ & 3 & 49 & 48 & 4,4 & 4,3 & 20,5 & 25 & 0,9 \\
\hline Bgjc & $72-102$ & 5 & 34 & 61 & 3,8 & 3,9 & 26,9 & 19 & 4,2 \\
\hline $\mathrm{BCgc}$ & $102-128$ & 4 & 39 & 57 & 4,2 & 3,5 & 27,8 & 27 & 4,6 \\
\hline $\mathrm{Cg} 1$ & $128-165$ & 2 & 40 & 58 & 6,5 & 3,3 & 37,4 & 76 & 14,9 \\
\hline $\mathrm{Cg} 2$ & $165-180$ & 2 & 34 & 64 & 7,5 & 3,4 & 40,9 & 87 & 19,0 \\
\hline \multicolumn{10}{|c|}{ Ei hapan sulfaattimaa } \\
\hline Ap & $0-28$ & 18 & 41 & 41 & 6,2 & 5,4 & 24,0 & 83 & 0,9 \\
\hline Bg1 & $28-60$ & 16 & 40 & 44 & 4,9 & 4,6 & 14,2 & 65 & 0,8 \\
\hline $\mathrm{Bg} 2$ & $60-70$ & 4 & 54 & 42 & 4,8 & 4,4 & 12,2 & 75 & 0,6 \\
\hline $\mathrm{BC}$ & $70-100$ & 3 & 13 & 84 & 4,4 & 4,2 & 23,4 & 76 & 0,9 \\
\hline $1 \mathrm{Cg}$ & $100-117$ & 68 & 23 & 9 & 5,2 & - & 2,0 & 78 & $<0,1$ \\
\hline $2 \mathrm{Cg}$ & $117-165$ & 2 & 12 & 86 & 6,2 & 5,6 & 21,2 & 90 & 0,5 \\
\hline
\end{tabular}

\section{Tulokset}

Happamassa sulfaattimaassa orgaanisen hiilen pitoisuus pieneni muokkauskerroksen 4,2 \%:sta Bkerroksen 1,9\%:iin. Vaihtumiskerroksessa hiilipitoisuus oli kuitenkin ylempää kerrosta suurempi (BC $\left.2,5 \% \quad \mathrm{C}_{\mathrm{org}}\right)$, ja pitoisuus kasvoi edelleen C-kerroksessa $\left(3,2 \% \mathrm{C}_{\mathrm{org}}\right)$. Vertailumaan muokkauskerroksessa hiilen pitoisuus oli samaa suuruusluokkaa kuin happamassa sulfaattimaassa (Ap $4 \% \mathrm{C}_{\text {org }}$ ), mutta pohjamaassa merkitsevästi pienempi (C-kerrokset $\left.0,3 \% \mathrm{C}_{\text {org }}, \mathrm{P}<0,001\right)$. Orgaanisen hiilen ja kokonaistypen typen suhde oli noin 10 happaman sulfaattimaan muokkauskerroksessa ja kaikissa muissa tutkituissa horisonteissa 8.

Kummassakin maaprofiilissa kokonaistypen jakautuminen eri maakerroksiin noudatteli hiilen jakautumista. Nitraattityppeä oli molemmissa maissa pohjaveden yläpuolella olevissa kerroksissa, mutta pysyvästi vedenalaisista kerroksista sitä ei mitattu lainkaan. Nitriitin pitoisuudet jäivät aina alle määritysrajan. Ammoniumtyppipitoisuudet olivat kummankin maan pohjakerroksissa pintakerroksien pitoisuuksia suurempia. Happaman sulfaattimaan pohjakerroksen pitoisuudet olivat merkitsevästi suurempia kuin tavanomaisen maan $(\mathrm{P}<0,001)$. Maaprofiileille lasketut hiili - ja typpivarannot erosivat toisistaan huomattavasti syvissä maakerroksissa kohdalla. Happaman sulfaattimaan pohjaveden alapuolella olevien kerrosten typpivarat hehtaaria kohti olivat110 $\mathrm{Mg} \mathrm{C}_{\text {org }}, 15 \mathrm{Mg} \mathrm{N}$ tot ja $\mathrm{N}_{\min } 330 \mathrm{~kg}$ ja tavanomaisen peltomaan pohjakerroksen varannot olivat $30 \mathrm{Mg} \mathrm{C}_{\text {org }}, 5 \mathrm{Mg} \mathrm{N} \mathrm{N}_{\text {tot }}$ and $\mathrm{N}_{\min } 110 \mathrm{~kg}$ (kuva 1).

Tutkituissa maaprofiileissa maahengitys vaihteli suuresti kerroksesta toiseen. Tavanomaisessa maassa suurimmat arvot mitattiin muokkauskerroksesta, jonka alapuolella maahengitys pieneni. Sitä vastoin happamassa sulfaattimaassa suurimmat arvot mitattiin pohjamaasta (kuva 2a), ja pienimmät B-horisontista. Happaman sulfaattimaan C-horisontissa maahengitys oli $2,1 \mu \mathrm{g} \mathrm{CO}_{2}-\mathrm{C} \mathrm{g}^{-1} \mathrm{~h}^{-1}$, vastaava arvo tavanomaisessa maassa oli $0,5 \mu \mathrm{g} \mathrm{CO}_{2}-\mathrm{C} \mathrm{g}^{-1} \mathrm{~h}^{-1}$. 


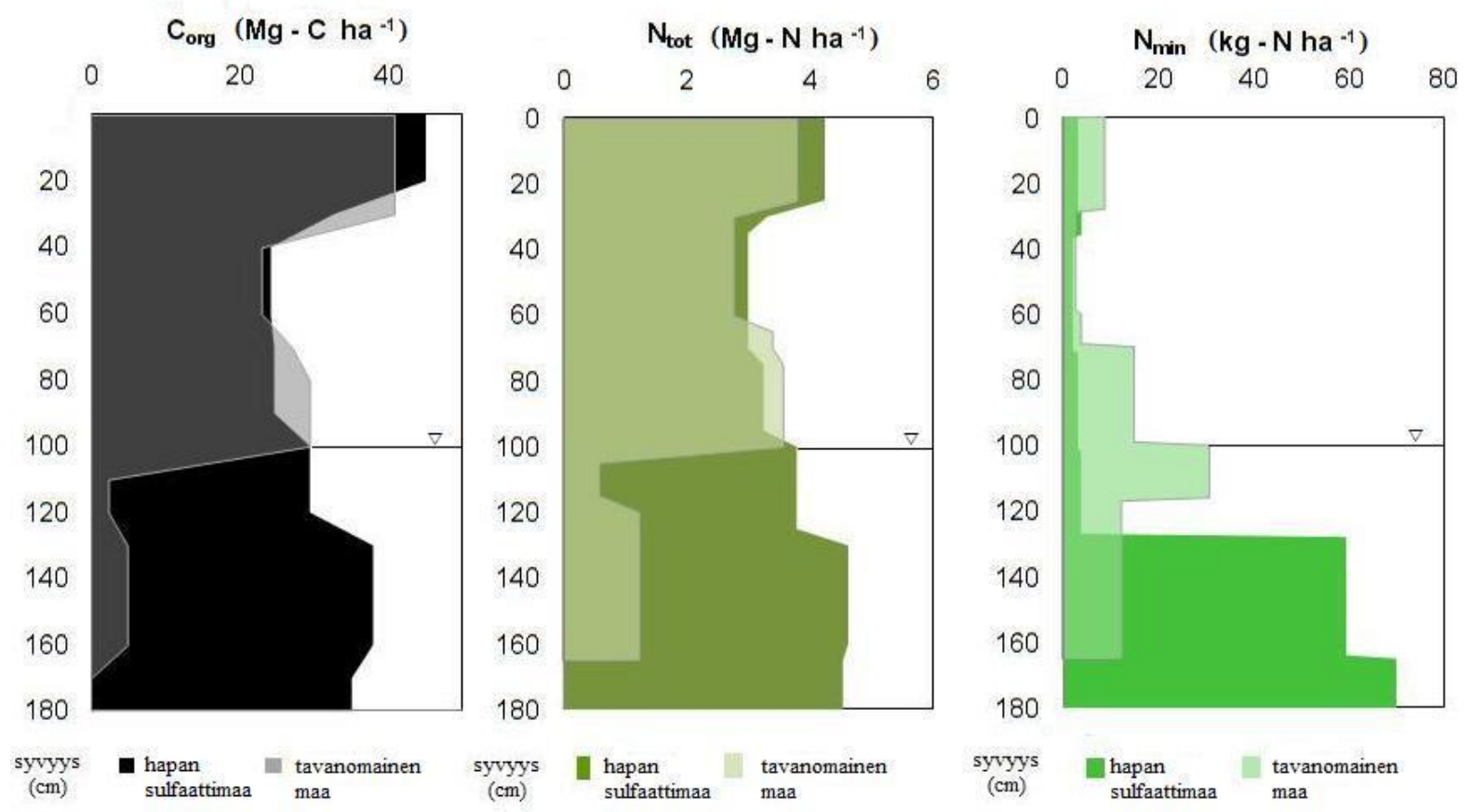

Kuva 1. Happaman sulfaattimaan ja tavanomaisen maan hiili-, kokonais- ja mineraalityppivarannot maaprofiilissa syvyyteen $165-180 \mathrm{~cm}$ asti. Kuvaan piirretty pohjavedenpinta $(\nabla)$ määrittelee pysyvästi pohjaveden alapuolella olevat maakerrokset (Simek ym., 2011).

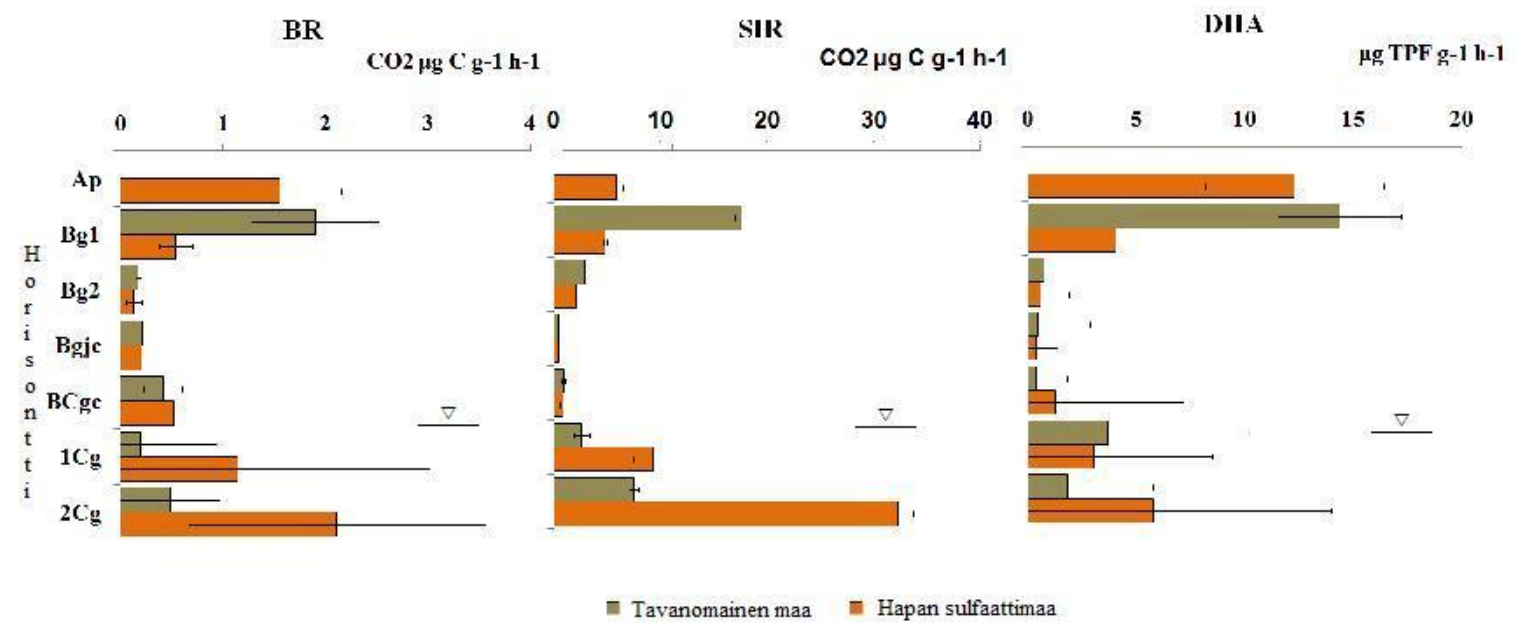

Kuva 2. Maahengitys (BR) (a), substraatilla indusoitu maahengitys (SIR) (b) ja dehydrogenaasi-entsyymin aktiivisuus (DHA) (c) happaman sulfaattimaan ja tavanomaisen maan eri kerroksissa (keskiarvo ja keskiarvon keskivirhe $(\mathrm{SEM}) \mathrm{n}=5)$. Kuvaan piirretty pohjavedenpinta $(\underline{\nabla})$ määrittelee pysyvästi pohjaveden alapuolella olevat maakerrokset (Simek ym. 2011).

Substraatilla indusoidun maahengitys (SIR) vaihteli syvyyden suhteen samaan tapaan kuin maahengitys (kuva 2b). C-horisontin SIR happamassa sulfaattimaassa $\left(33 \mu \mathrm{g} \mathrm{CO}_{2}-\mathrm{C} \mathrm{g}^{-1} \mathrm{~h}^{-1}\right)$ oli yli nelinkertainen tavanomaiseen maahan verrattuna $\left(7,5 \mu \mathrm{g} \mathrm{CO}_{2}-\mathrm{C} \mathrm{g}^{-1} \mathrm{~h}^{-1}\right)$. Dehydrogenaasientsyymin aktiivisuus (DHA) muuttui samalla tavoin kuin BR ja SIR, joskin suurimmat DHA tuloksetmitattiin molempien maiden muokkauskerroksesta (kuva 2b), ja pienimmät B-horisontista. Pohjamaan suurin tulos saatiin happaman sulfaattimaan syvimmästä maakerroksesta (DHA $5.7 \mu \mathrm{g} \mathrm{TPF} \mathrm{g}^{-1} \mathrm{~h}^{-1}$ ). 


\section{Tuloksien tarkastelu}

Happamien sulfaattimaiden runsaat orgaanisen aineen varannot ovat peräisin sedimenttien muodostumisen ajoilta noin $4000-7000$ vuotta sitten. Nämä rautasulfideja sisältävät kerrokset ovat olleet vedellä kyllästyneinä muodostumisestaan lähtien, ja ne ovat edelleen kemiallisesti pelkistyneitä ja happamuudeltaan lähes neutraaleja. Pysyvästi vedellä kyllästyneet olot ovat ilmeinen syy maiden muodostumisvaiheessa kertyneen orgaanisen hiilivarannon säilymiseen. Kuivatuksen onkin todettu pienentävän happamien sulfaattimaiden hiilivarantoa (Smiles, 2009: Page \& Dalal, 2011). Pohjamaakerrosten pieni hiili-typpi -suhde viittaa suureen typen mineralisoitumispotentiaaliin. Näiden kerrostumien orgaaninen aine on ajan mittaan mineralisoitunut ja vapauttanut ammoniumtyppeä maahan. Vuosituhansien kuluessa sitä on todennäköisesti akkumuloitunut maahan runsaasti, koska hapettomuus on estänyt nitrifikaation. Vaikka happaman sulfaattimaan syvien maakerrosten mineraalitypen varannot ovat suuria verrattuna tavanomaisesti pohjamaassa tavattuihin (vain muutaman $\mathrm{kg} \mathrm{ha}^{-1}$ ) varantoihin (Sippola ja Yläranta, 1985), ei arviomme varannoista kuitenkaan vielä sisällä ammoniumin mahdollista fiksaatiota vermikuliittiin (Kaila, 1965). Käyttämämme uuttoliuos $(2 \mathrm{M} \mathrm{KCl})$ ei uuta tällaistä spesifisesti maahan sitoutunutta typpeä. Mineraalitypen varannot voivat siksi olla vielä arvioimaamme suuremmat.

Maahengitys kuvaa pääasiassa maan heterotrofisten organismien aktiivisuutta, joka on yleensä vilkkainta peltomaiden muokkauskerroksessa. Tutkimuksessamme tavanomaisessa maassa maahengitys oli odotusten mukaisesti suurinta muokkauskerroksessa. Sen sijaan happamassa sulfaattimaassa maahengitys kasvoi syvissä kerroksissa jopa suuremmaksi kuin pintamaassa. Tähän oli syynä kerrosten runsaat orgaanisen aineksen ja mineraalitypen varannot, sillä maahengitys kasvaa mikrobien ja helposti hajotettavan orgaanisen aineksen määrän lisääntyessä.

Tavanomaisen maan SIR:n spatiaalinen jakautuminen maaprofiilissa vastasi muualla maatalousmaissa havaittua syvyyden suhteen vähenevää trendiä (Fierer ym., 2003), josta happaman sulfaattimaan SIR:n spatiaalinen jakautuminen selvästi poikkesi. Koska SIR:ssä maahan lisätään helposti mikrobien käytettävissä olevaa orgaanista ainesta, se kuvaa olosuhteiden muutoksiin nopeasti reagoivien kasvukykyisten mikrobien määrää. Tulostemme perusteella happaman sulfaattimaan syvissä kerroksissa on runsaasti mikrobeja, jotka ovat aktivoituneet olosuhteiden muuttuessa suotuisimmaksi näytteen oton ja inkuboinnin aikana. Vastaavanlainen havainto on tehty myös toisessa, vielä vanhemmista maakerroksista tehdyssä tutkimuksessa, jossa mikrobit aktivoituivat olosuhteiden parantuessa (Elhottova ym., 2006). Happaman sulfaattimaan syvissä kerroksissa nyt lepotilassa olevat mikrobit saattavat aktivoitua nopeasti, jos olosuhteet maassa muuttuvat niille suotuisiksi.

Eri kerrosten mikrobien aktiivisuutta mitattiin myös DHA:n avulla. Tulostemme mukaan kummassakin maassa on runsaasti aktiivisia mikrobeja muokkauskerroksessa, mutta niitä on myös happaman sulfaattimaan syvissä kerroksissa. Wlodarzyk (2002) löysi tulvitetuilla mailla positiivisen yhteyden DHA:n ja kasvihuonekaasujen muodostumisen välillä. Mittaamamme suuret DHA arvot happaman sulfaattimaan pohjamaassa voivat siis merkitä myös niiden suurta potentiaalia kasvihuonekaasujen emissioihin.

\section{Johtopäätökset}

Tutkimuksemme osoitti, että happaman sulfaattimaan pohjakerroksissa on tavanomaista maata suuremmat orgaanisen hiilen ja typen varannot. Pohjakerroksista löytyi myös mikrobiaktiivisuutta, mikä voi yhdessä runsaiden ravinnevarojen kanssa aiheuttaa kasvihuonekaasuemissioita, jos tällä hetkellä mikrobeille epäsuotuisat hapettomat olosuhteet muuttuvat hapellisiksi. Hapettomat olosuhteet voivat muuttua hapellisiksi pohjaveden pinnan laskiessa maankohoamisen tai kuivatuksen seurauksena. Maan mikrobien toiminta voi vilkastua myös, jos maan lämpötila nousee mahdollisen ilmastonmuutoksen seurauksena. Pilottitutkimuksemme osoitti, että lisätutkimuksille on tarvetta. 


\section{Kirjallisuus}

Brasher, B. R., Franzmeier, D.P., Valassis, V.T. \& Davidson, S.E. 1966. Use of saran resin to coat natural soil clods for bulk density and water retention measurements. Soil Science 101:108.

Casida, L.E., Klein, D.A. \& Santoro, T. 1964. Soil dehydrogenase activity. Soil Science 98: 371-376.

Dick, R. P., Breakwell, D. P. \& Turco, R. F. 1996. Soil enzyme activities and biodiversity measurements as integrative microbiological indicators. Teoksessa: Doran, J.W., Jones, A.J. (toim.), Methods for assessing soil quality. SSSA Special publication 49, SSSA, Madison, Wi, USA, ss. 247-271.

Elhottova, D., Kristufek, V., Frouz, J., Novakova, A. \& Chronakova, A. 2006. Screening for microbial markers in Miocene sediment exposed during open-cast brown coal mining. Antonie Van Leeuwenhoek International Journal of General and Molecular Microbiology 89:459-463.

Esala, M. J. 1995. Changes in the extractable ammonium-nitrogen and nitrate-nitrogen contents of soil samples during freezing and thawing. Communications in soil science and plant analysis 26:61-68.

Fierer, N., Schimel J.P. \& Holden P.A. 2003. Variations in microbial community composition through two soil depth profiles. Soil Biology \& Biochemistry 35:167-176

Fältmarsch, R.M., Åström, M.E. \& Vuori, K. 2008. Environmental risks of metals mobilised from acid sulphate soils in Finland: a literature review. Boreal Environment Research 13:444-456.

Joukainen, S. \& Yli-Halla, M. 2003. Environmental impacts and acid loads from deep sulfidic layers of two well-drained acid sulfate soils in western Finland. Agriculture Ecosystems \& Environment 95:297-309.

Mokma, D.L., Yli-Halla, M. \& Hartikainen, H. 2000. Soils in a young landscape on the coast of southern Finland. Agricultural and Food Science in Finland 9:291-302.

Paasonen-Kivekäs, M. \& Yli-Halla, M. 2005. A comparison of nitrogen and carbon reserves in acid sulphate and non acid sulphate soils in western Finland. Agricultural and Food Science 14: 57-69.

Page,K.L. \& Dalal, R.C. 2011, Contribution of natural and drained wetland systems to carbon stocks, $\mathrm{CO}_{2}$, $\mathrm{N}_{2} \mathrm{O}$, and $\mathrm{CH}_{4}$ fluxes: an Australian perspective. Soil Research, 49:377-388.

Simek, M., Virtanen, S., Kristufek, V., Simojoki, A. \& Yli-Halla, M. 2011, Evidence of rich microbial communities in the subsoil of a boreal acid sulphate soil conducive to greenhouse gas emissions. Agriculture, Ecosystems and Environment 140:113-122.

Sippola, J. \& Yläranta, T. 1985. Mineral nitrogen reserves in soil and nitrogen fertilization of barley. Annales Agriculturae Fenniae. 24:117-123.

Smiles, D. E. 2009. Quantifying carbon and sulphate loss in drained acid sulphate soils. European Journal of Soil Science, 60:64-70.

Wlodarczyk, T., Stepniewski, W. \& Brzezinska, M. 2002. Dehydrogenase activity, redox potential, and emissions of carbon dioxide and nitrous oxide from Cambisols under flooding conditions. Biology and Fertility of Soils 36:200-206.

Yli-Halla, M., Puustinen, M. \& Koskiaho, J. 1999. Area of cultivated acid sulfate soils in Finland. Soil Use and Management 15:62-67.

Yli-Halla, M., Mokma, D.L., Peltovuori, T. \& Sippola, J. 2000. Suomalaisia maaprofiileja. Maatalouden tutkimuskeskuksen julkaisuja. Sarja A 78. 32 s. 